\title{
Toothbrushing EEG artifact recorded from chronically implanted subdural electrodes
}

的

Figure Artifact arising from electrode-jackbox connections generated from toothbrushing during intracranial EEG

A
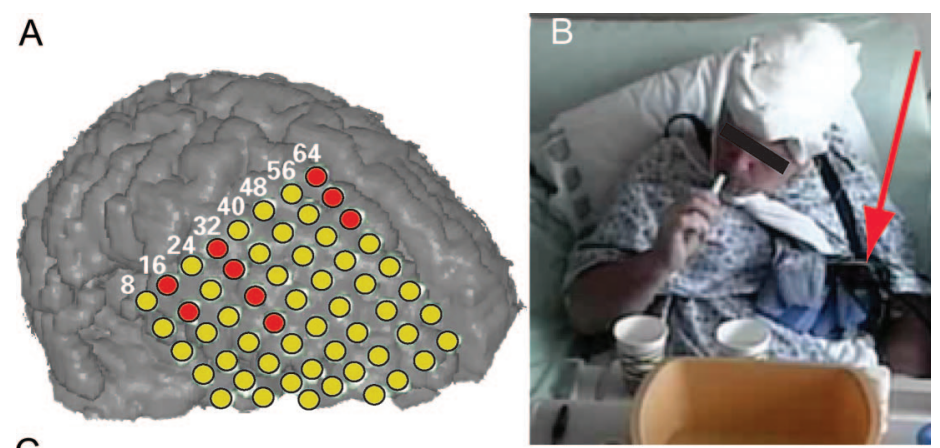

C

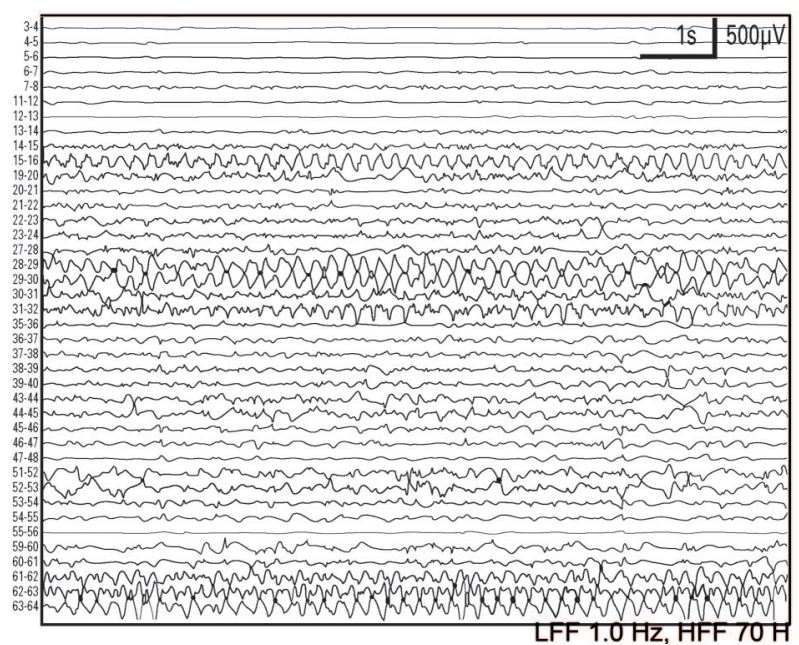

(A) Three-dimensional MRI of a right frontotemporal subdural grid. Red, affected electrodes. Note: The grid has 64 electrodes. Not all electrodes are shown. (B) Patient brushing his teeth causing movement of jackbox (arrow) disproportionately affecting posterior rows of electrode inputs. (C) Nonevolving, rhythmic, $\sim 5 \mathrm{~Hz}$ artifact induced by jackbox-electrode movement.

A 45-year-old man had epilepsy beginning at 13 years after herpes simplex virus encephalitis and subsequent right frontotemporal encephalomalacia. Intracranial EEG recording were performed. Rhythmic EEG artifacts, often seen on scalp EEG, can still occur during intracranial recordings from the connections linking the patient to the machine. A software-detected "seizure" revealed activity in the posterior portions of a subdural grid (figure, A, red) that corresponded to toothbrushing (figure, B; video on the Neurology ${ }^{\circledR}$ Web site at www.neurology.org), but did not evolve spatially or temporally (figure, C). The source was current induced by the movement of electrodes plugged into the posterior rows of the 232 -input jackbox/amplifiers worn suspended in a pouch about the patient's chest.

Supplemental data at www.neurology.org
Howard P. Goodkin, MD, PhD, Mark Quigg, MD, Charlottesville, VA

Disclosure: Dr. Goodkin serves on scientific advisory boards for the Tuberous Sclerosis Alliance and CURE; serves on the editorial boards of Neurology ${ }^{\circledR}$ and Surgical Neurology International; has served as a consultant to MedImmune; and receives research support from the NIH (NS048413 [PI] and NS067439 [PI]). Dr. Quigg is listed as author on a patent re: Actigraphy system for seizure characterization; receives royalties from the publication of EEG Pearls (Elsevier, 2006); and receives research support from the NIH (NS058634 [Co-PI]).

Address correspondence and reprint requests to Dr. Howard P. Goodkin, Department of Neurology, University of Virginia, PO Box 800394 , Charlottesville,VA 22908; Hpg9v@virginia.edu 


\title{
Neurology
}

\author{
Toothbrushing EEG artifact recorded from chronically implanted subdural electrodes \\ Howard P. Goodkin and Mark Quigg \\ Neurology 2010;75;1850 \\ DOI 10.1212/WNL.0b013e3181fd62fd
}

This information is current as of November 15, 2010

\section{Updated Information \& Services \\ Supplementary Material \\ Citations \\ Subspecialty Collections}

Permissions \& Licensing

Reprints including high resolution figures, can be found at: http://n.neurology.org/content/75/20/1850.full

Supplementary material can be found at: http://n.neurology.org/content/suppl/2010/11/14/75.20.1850.DC1

This article has been cited by 1 HighWire-hosted articles: http://n.neurology.org/content/75/20/1850.full\#\#otherarticles

This article, along with others on similar topics, appears in the following collection(s):

EEG

http://n.neurology.org/cgi/collection/eeg

EEG; see Epilepsy/Seizures

http://n.neurology.org/cgi/collection/eeg_see_epilepsy-seizures

Epilepsy monitoring

http://n.neurology.org/cgi/collection/epilepsy_monitoring _

Intracranial electrodes

http://n.neurology.org/cgi/collection/intracranial_electrodes

Information about reproducing this article in parts (figures,tables) or in its entirety can be found online at:

http://www.neurology.org/about/about_the_journal\#permissions

Information about ordering reprints can be found online:

http://n.neurology.org/subscribers/advertise

Neurology ${ }^{\circledR}$ is the official journal of the American Academy of Neurology. Published continuously since 1951, it is now a weekly with 48 issues per year. Copyright Copyright (? 2010 by AAN Enterprises, Inc.. All rights reserved. Print ISSN: 0028-3878. Online ISSN: 1526-632X.

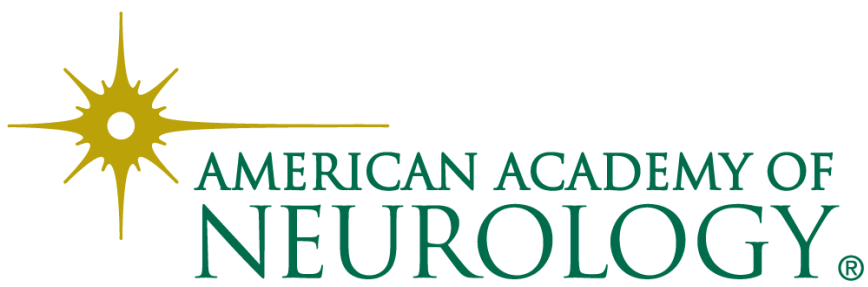

